\title{
INTERAKSI SOSIAL DAN KRIMINALITAS DI PERUMAHAN
}

\author{
Nangkula Utaberta \\ Peneliti Pusat Kajian Alam Bina Dunia Melayu, Universiti Teknologi Malaysia \\ Email : nangkula_arch@yahoo.com
}

\begin{abstract}
ABSTRAK
Keamanan perumahan terhadap tindak kriminalitas, menjadi faktor utama seseorang memilih lokasi rumah tinggal. Tindak kriminalitas terjadi karena berbagai penyebab. Salah satu faktor penyebab timbulnya tindak kriminalitas adalah terkait dengan bidang arsitektur, yaitu bentuk site plan perumahan. Bentuk-bentuk gubahan massa ada yang mudah menimbulkan tindak kriminal, akan tetapi ada juga bentuk gubahan massa yang membuat seseorang berpikir panjang untuk melakukan tindak kriminal. Kemudahan untuk melarikan diri menjadi pertimbangan utama seseorang berani melakukan tindak kriminal. Disamping faktor fisik dalam bentuk site plan, faktor lainnya adalah budaya kekerabatan penghuni, dimana hubungan antar penghuni yang erat, akan membuat setiap orang di dalam lingkungan akan saling peduli dengan orang lainnya. Hal inilah yang mendukung keamanan lingkungan.
\end{abstract}

\section{Kata Kunci: perumahan, interaksi sosial, kriminalitas}

\section{PENDAHULUAN}

Jika kita perhatikan berbagai pemberitaan di media cetak maupun media elektronik akhir-akhir ini kita akan mendapatkan sebuah kenyataan yang mengejutkan sekaligus menakutkan. Begitu besarnya angka kriminalitas baik berupa pencurian dan perampokan bahkan yang disertai pembunuhan pada berbagai kompleks perumahan. Tulisan ini berusaha mengangkat aspek arsitektural dan masalah perancangan sebagai penyebab dari berbagai kriminalitas tersebut serta melihatnya dalam sebuah konteks masyarakat sebagai sebuah kesatuan bagian yang utuh. Diharapkan dari tulisan ini kita dapat melihat aspek arsitektur sebagai sebuah bagian yang integral dengan masalah kemasyarakatan dan memberikan sebuah solusi terhadap masalah kriminal ini dengan sebuah penyelesaian yang utuh dan integrative. Ada dua masalah utama yang dalam pandangan penulis berhubungan erat dengan masalah kriminalitas pada sebuah perumahan, yaitu pertama berhubungan dengan bagaimana pola hidup individualistis dari masyarakat yang tinggal; di perumahan tersebut dan yang kedua adalah masalah perancangan dari kompleks perumahan yang memungkinkan terjadinya kriminalitas.

\section{Pola Hidup Individualistis dan Masalah Kriminalitas}

Sebagai orang yang pernah hidup dan besar di lingkungan perkampungan, penulis masih ingat sebuah kejadian semasa kecil dulu. Suatu ketika ada 3 orang pencuri masuk dan mencuri di kampung kami. Rupanya mereka telah mengincar rumah yang bersangkutan sejak seminggu sebelumnya. Masyarakat kampung sendiri telah curiga kepada mereka sebagai orang asing yang keluar masuk kampung kami. Akhirnya terjadilah peristiwa itu. Tiga orang perampok berhasil masuk ke salah satu rumah warga dan mencuri sejumlah perhiasan dan barang elektronik. Namun pemilik rumah cukup bernasib baik, salah seorang penghuni rumah bangun dan berteriak memanggil warga. Karena antar warga relatif dekat, warga segera mendengar panggilan tersebut dan mereka segera keluar. Pengejaran terhadap 3 pencuri tersebutpun terjadi. Tak sampai 15 menit seluruh pencuri sudah tertangkap dan diserahkan kepada pihak berwajib. Para pencuri tersebut salah memilih tempat bersembunyi bahkan satu orang tersesat masuk rumah seorang warga karena tidak mengenal situasi dan kondisi di desa tersebut. Sebuah kisah yang bagi beberapa orang mungkin biasa dan memang biasa terjadi disekitar kita. Namun sebagai seorang yang 
mendapat pendidikan arsitektur saya melihatnya sebagai suatu hal yang sangat berbeda. Kisah ini mengajarkan berbagai pelajaran barharga tentang interaksi dari pola hidup warga, sistem perancangan rumah, dan sistem sosial kemasyarakatan dan pengaruhnya terhadap antisipasi dan penangkalan dari kampung dan kawasan tersebut terhadap kriminalisasi.

Hal yang juga menarik adalah sebuah kenyataan bahwa kasus kriminalitas seperti pencurian dan perampokan sebagaimana dijelaskan oleh media cetak dan elektronik justru banyak terjadi pada kompleks perumahan terutama perumahan yang mewah dibandingklan dengan kawasan kampung atau pedesaan. Hal ini mungkin terjadi karena memang barang-barang berharga adanya di perumahan mewah tersebut (kalau di kampung apa yang mau dicuri), namun sebab lain mungkin karena memang mencuri atau merampok lingkungan perumahan apalagi perumahan mewah memang lebih mudah daripada mencuri dan merampok di perkampungan.

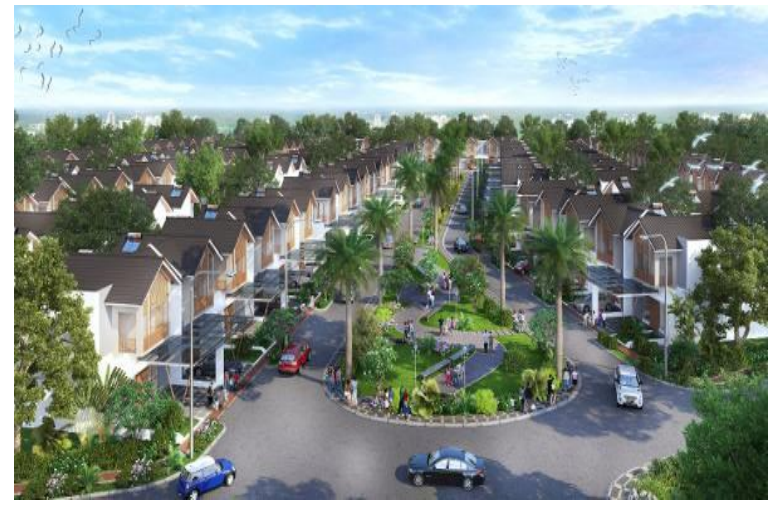

Gambar 1. Perumahan lengang, menjadi sasaran empuk pencuri dan perampok Sumber : http://www.housing-

estate.com/read/2014/09/30/citra-raya-tangerangluncurkan-cluster-baru/

Jika kita pelajari sistem hidup yang ada di perkampungan atau daerah perumahan yang sederhana, kita akan mendapatkan sebuah sistem kehidupan yang sangat rapat. Orang satu RT bahkan RW akan saling mengenal satu sama lain. Seorang ibu akan mengenal seluruh anak bahkan anggota keluarga dari tetangganya yang berada di rukun tetangga (RT) lain. Jika salah seorang anak berulang tahun atau ada anak yang baru lulus kuliah suatu keluarga akan membagi- bagikan nasi kuning ke seluruh kampung. Walaupun kadangkala menimbulkan masalah privasi karena banyaknya gosip yang sering beredar hubungan antar tetangga ini menjamin suatu interaksi yang sangat positif. Dari hubungan yang dekat inilah antara keluarga yang satu dengan yang lain akan saling menjaga sehingga kriminalitas dapat ditekan.

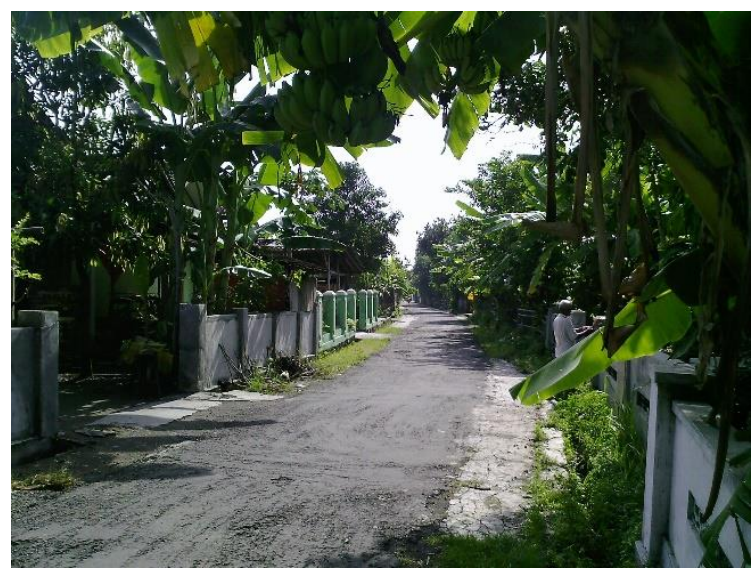

Gambar 2. Perumahan di perkampungan , memungkinkan sebuah interaksi positif antar warganya.

Sumber :

https://yuliyanto2006.wordpress.com/2010/01/

Sebaliknya pada perumahan yang mewah atau menengah keatas, kita akan mendapat sebuah lingkungan yang sama sekali berbeda. Antara tetangga bersebelahan rumah pun akan tidak saling mengenal. Setiap rumah sibuk dengan aktivitas keluarganya sendiri-sendiri. Rutinitas sehari-hari seperti bangun-berangkat kerja-pulang kerja-tidur menjadi suatu kegiatan yang terjadi seharihari, kita bahkan tidak sempat menyapa tetangga kita, apalagi mengetahui nama anakanak mereka. Dalam lingkungan seperti ini biasanya masalah keamanan lebih diserahkan kepada satpam yang menjaga gerbang kompleks dan berpatroli siang dan malam. Lingkungan seperti ini lah yang rawan dari kriminalitas.

Seorang warga tidak akan peduli ketika seorang asing masuk ke rumah tetangganya karena dia memang tidak menyadari orang tersebut sebagai orang asing. Bagaimana dia sadar, jika dia tidak pernah mengenalnya? itulah sebabnya pada salah satu kompleks perumahan menengah ke atas di dekat rumah saya, angka kriminalitas begitu tinggi. Dengan begitu banyaknya satpam yang menjaga kompleks tersebut, hampir setiap minggu 
terjadi pencurian kendaraan, bahkan sebuah kendaraan yang sedang dicuci pun dapat hilang karena lengah dijaga pemiliknya.

\section{PERENCANAAN PERUMAHAN PENDU- KUNG KRIMINALITAS}

Selain masalah sosial sebagaimana yang penulis ceritakan sebelumnya, masalah perancangan dan aspek teknis dari desain rumah itu sendiri memungkinkan hal tersebut. Perancangan rumah dengan sistem grid yang memanjang (kadangkala kelewat panjang) jelas tidak mendukung interaksi sosial antar warga. Metode perancangan ini memungkinkan penempatan jumlah rumah yang banyak namun tidak mendukung pertautan hati yang banyak diantara penghuninya.

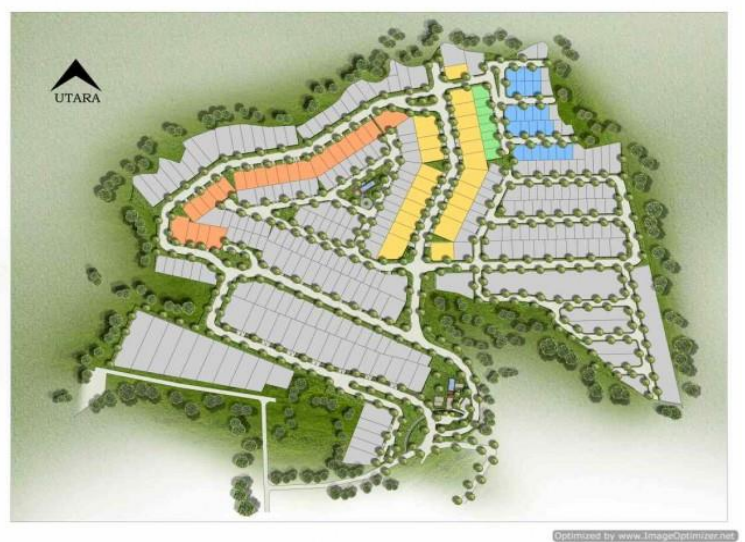

Gambar 3. Metode Perancangan yang menggunakan sistem grid mengundang kejahatan. Sumber: http://www.rumah123.com/perumahanbaru/detail-siteplan-perumahan-baru-di-bukit-sarisemarang-682-id.html

Mungkin jika kita membuat dengan sistem pengelompokan (cluster) dengan sebuah ruang publik bersama sebagaimana denah dibawah ini, kita sedikit banyak akan mendukung interaksi yang positif antar warga. Seorang warga setidaknya dapat melihat aktivitas dari tetangganya sehingga mendorong mereka untuk saling kenal.

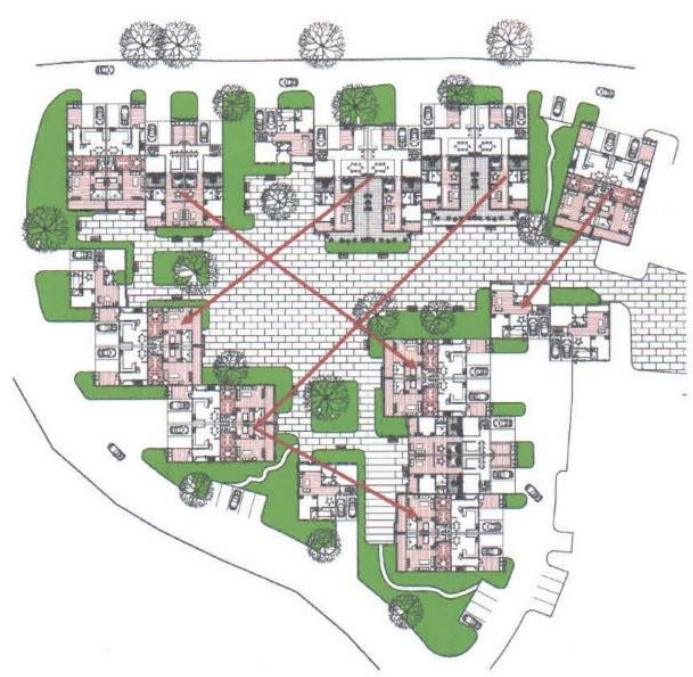

Gambar 4 : Perancangan dengan sistem cluster (pengelompokan) memungkinkan interaksi antara warga.

Sumber: http://www.rumah123.com/perumahanbaru/detail-siteplan-perumahan-baru-di-bukit-sarisemarang-682-id.html

Sistem perancangan secara berkelompok juga memungkinkan sebuah sistem territorial kawasan yang kuat. Hal ini memungkinkan setiap kelompok mampu mengelola keamanan (mereka hanya perlu mengenal sedikit orang) di kawasannya sebagaimana usaha dan pengelolaan territorialitas pada masyarakat tradisional. Setiap anggota kelompok akan merasa bertanggung jawab terhadap wilayahnya sehingga memungkinkan unit-unit kecil penangkal kriminalitas. Masalah teknis yang sering mendukung kejahatan adalah perletakan tiang listrik atau telpon di samping pagar rumah yang seringkali menjadi alat masuk yang mudah bagi pencuri, atau perancangan jendela dan pintu yang seringkali kurang memadai. Penggunaan teralis yang biasa digunakan, sebenarnya merupakan sarana yang sangat efektif untuk mencegah pencuri, namun penggunaan teralis memiliki sebuah potensi "senjata makan tuan" yang mengerikan ketika terjadi kebakaran. Pada banyak kasus kebakaran, justru teralis inilah yang menghalangi orang untuk menyelamatkan diri. Lagipula para kriminal itulah yang seharusnya dipenjara bukan kita. 


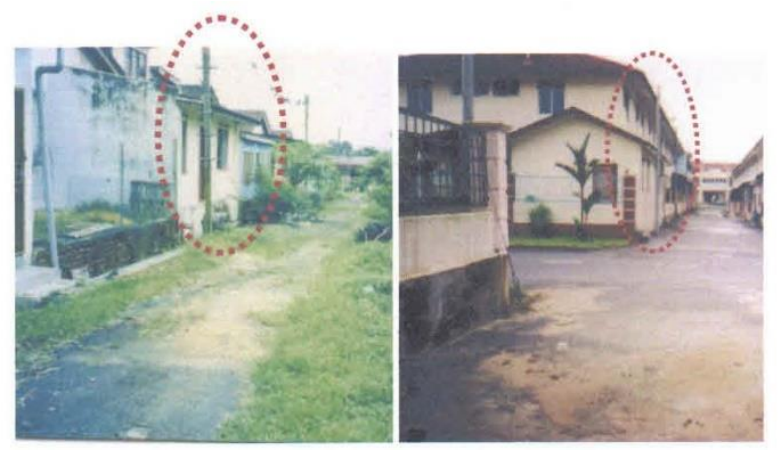

Gambar 5. Perletakan kabel telpon dan tiang listrik yang seringkali menjadi sarana bagi masuknya pencuri kedalam rumah. Sumber: Survei, 2002
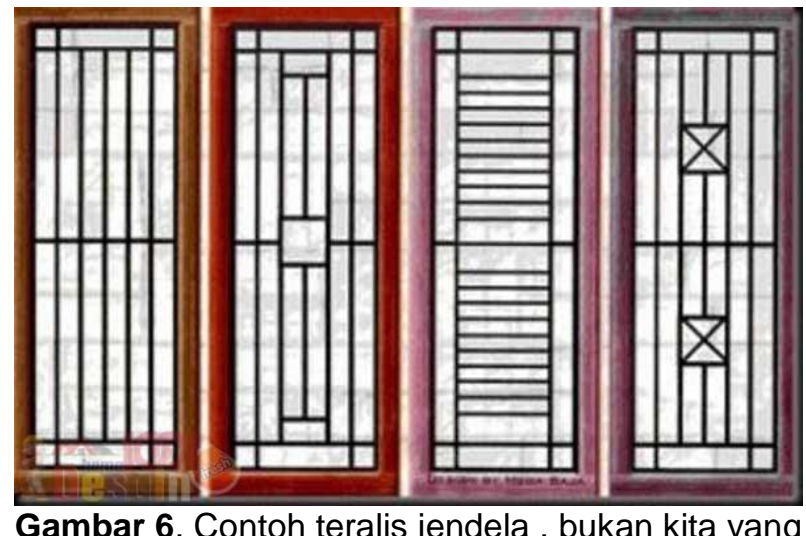

Gambar 6. Contoh teralis jendela, bukan kita yang seharusnya dipenjara. Sumber :

http://www.medan.indonetwork.co.id/huruftimbul_st ainles/1946690
Pemeliharaan anjing pun seringkali tidak banyak membantu, karena banyak perampok yang kemudian menggunakan makanan anjing dengan obat tidur untuk mengamankan mereka. Penggunaan satpam sebagaimana anjing pun sering menimbulkan masalah karena kadangkala merekalah yang menjadi pencurinya karena tidak tahan dengan kemewahan yang ditunjukkan oleh pemilik rumah. Yang jelas baik pemeliharaan anjing maupun penyewaan satpam memerlukan biaya dan perawatan yang tidak kecil.

\section{PENUTUP}

Pengamanan terhadap lingkungan menjadi tanggung jawab bersama antar penghuni perumahan. Pengamanan dengan memelihara penjagaan di hati tetangga kita sebagai suatu metode yang jauh lebih baik atau setidaknya lebih murah dengan manfaat yang luar biasa.

\section{DAFTAR PUSTAKA}

https://yuliyanto2006.wordpress.com/2010/01/

https://yuliyanto2006.wordpress.com/2010/01/

http://www.housing-estate.com/read/2014/09/30/citra-raya-tangerang-luncurkan-cluster-baru/

http://www.medan.indonetwork.co.id/huruftimbul_stainles/1946690 